\title{
Biofuel energy: Resources, production and its impact on environment
}

\author{
Vijander Kumar ${ }^{* 1}$ and Sandeep Kumar ${ }^{2}$ \\ ${ }^{1}$ Assistant Professor Sant Longowal Institute of Engineering \& Technology, Longowal -148106 India \\ ${ }^{2}$ Assistant Professor Lovely Professional University Phagwara - 144411 India
}

\begin{abstract}
In order to fulfil the energy demand of world, there is a need to adopt a new energy system which is based on use of renewable energies resources. Emphasis should be on integration of the various forms of renewable energy like solar energy, geothermal energy, wind energy and biofuels energy. These energy resources have potential to replace the dependency of world on fossil fuels if proper policies for utilization of these resources have to be adopt. Change in climate and independency of energy are master stroke for bioenergy development. Many researcher have focused on the biofuels performance in reducing carbon emissions, with questions marks on their potential in this respect. Governments of many countries are setting targets to enhance the proportion of biofuels in their energy mix for the purposes of fulfill their energy security and rural development. There are lot of benefits of biofuels energies like job creation and diversification of the economy in rural areas, reliable market for agricultural produce especially for energy crops especially in developing countries. In present review different biofuels sources with their impact on environment and amount of production biomass in world has been discussed
\end{abstract}

KEY WORDS: BIOFUELS, ENERGY, BIODIVERSITY, GREEN ENERGY, BIOMASS

\section{INTRODUCTION}

In last few decade world has obtained a period of intense economic growth. With economic growth the requirements of energy also increases securing future energy supplies in a shrinking energy market is vital if this is to continue. After several year when oil reserves have shown a pronounced drop, then it is highly necessary

\section{ARTICLE INFORMATION:}

*Corresponding Author: dvijander@gmail.com Received $3^{\text {rd } J a n, ~} 2018$

Accepted after revision $12^{\text {th }}$ March, 2018

BBRC Print ISSN: 0974-6455

Online ISSN: 2321-4007 CODEN: USA BBRCBA

. Thomson Reuters ISI ESC / Clarivate Analytics USA and

W. Crossref Indexed Journal

NAAS Journal Score 2017: 4.38 SJIF 2017: 4.196

- A Society of Science and Nature Publication, Bhopal India 2018. All rights reserved.

Online Contents Available at: http//www.bbrc.in/

DOI: $10.21786 / \mathrm{bbrc} / 11.1 / 23$ to find new sources. In last three decades the world is moving towards renewable energy resources such as solar energy, wind energy, geothermal energy and biofuels energy. The main concern of all these is that they are green sources of energy that is they have negligible harmful effect on environments

The term biofuels is being appropriated to refer just to fuels like ethanol and biodiesel, it should ideally imply 
fuels from plant-based sources, which can be produced, processed and consumed in diverse forms. Bioenergy can be defined as energy produced from any source of biomass; i.e. plants, animals, and organic waste. Biofuels account for only a small proportion of energy use, currently providing approximately 1\% of the global energy supply and approximately $4 \%$ of the global liquid transport fuel use. Despite its small current contribution to transport energy, the production of liquid biofuels has increased rapidly in recent years. This increase can be attributed in part to government targets and subsidies example EUs renewable energy target, which have been established to promote the use of biofuels for reasons of energy security, climate change mitigation, and rural development

\section{SOURCES OF BIOFUEL ENERGY}

The supply of biomass can be classified into two sections traditional biomass and modern biomass. Traditional biomass implies the use of sources like wood, crop residues, animal dung, and charcoal used for heating and cooking at the household level. Traditional biomass is an informal activity as it is generally collected by women and children from public lands or privately owned lands. Liquid biofuels for transportation like ethanol and biodiesel are one of the fastest-growing sources of alternative energy in the world today which comes under modern sources of biofuels. Sources of biomass energy can be categorized in the following three category : Agriculture, Forestry and Waste.
Conversion of agricultural residue to bioethanol by enzymatic treatments is done in many crops, (Prasad et.al 2007). India is the largest producer and consumer of coriander in the world. A coriander crop residue in India is estimated to produce $188.3 \mathrm{kT} / \mathrm{Yr}$ biomass having $22 \mathrm{MW}$ power potential and $5.2 \mathrm{Mcal} / \mathrm{sec}$. calorific potential, (Anil et. al 2015). This calorific value can be converted in bio-ethanol. Coriander is cultivated both for leaf as well as for seed; biomass in form of leaf of young plant is consumed, whereas the crop residue of the seed purpose coriander is left as an agricultural waste. The general practice adopted by farmers for management of that residual waste is using it for composting, or it is being burnt in the fields as it is not preferred by animals for feeding. Conversion of this biomass to bio-ethanol can be an opportunity for making biofuel. Biomass is coriander is highly variable as per the variety sown, production technology adopted, nutrient application, and environmental condition

Sugar and starch-based crops: Crops rich in sugar and starch like sugarcane and corn (maize), respectively, supply almost all the ethanol that is produced today. Other major crops being used include, wheat, sorghum, sugar beet, and cassava (Moonmoon et al. 2014). Technologies for conversion of sugar and starch are also the most technologically and commercially mature today

Most bioenergy systems can be explained using the schematic shown in figure 1

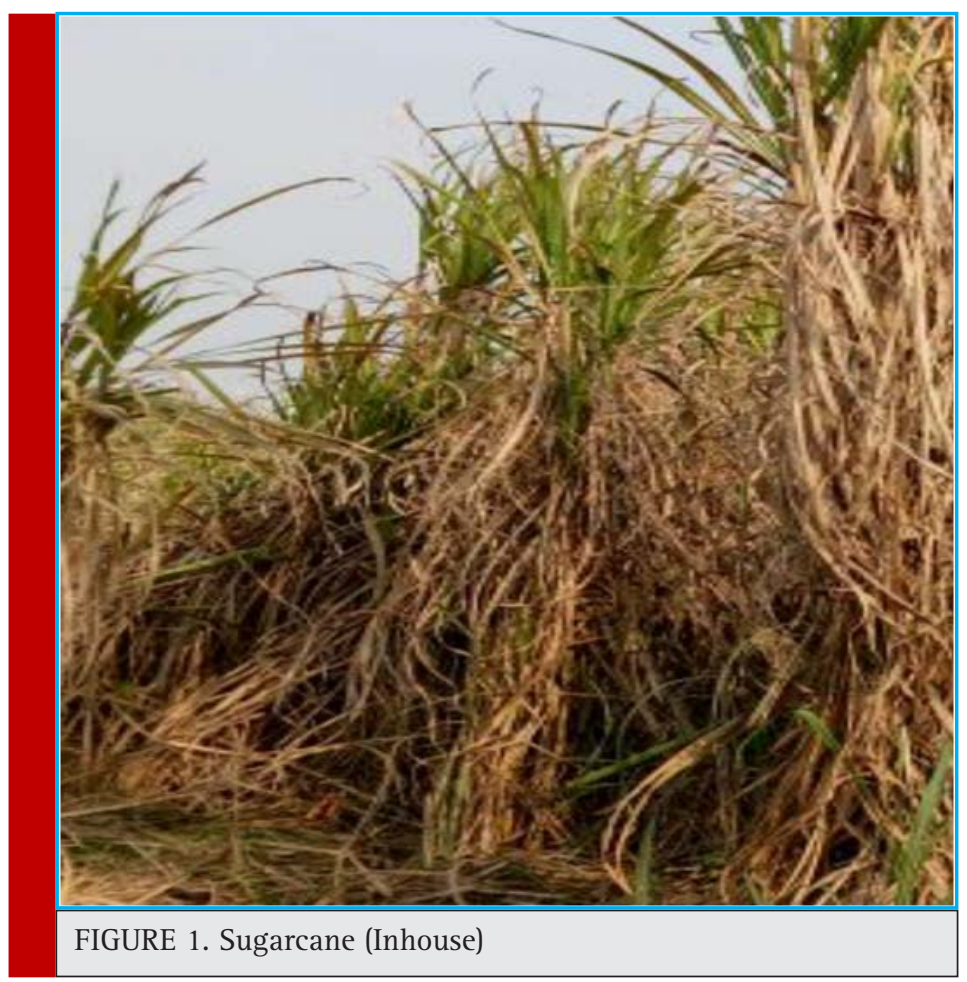




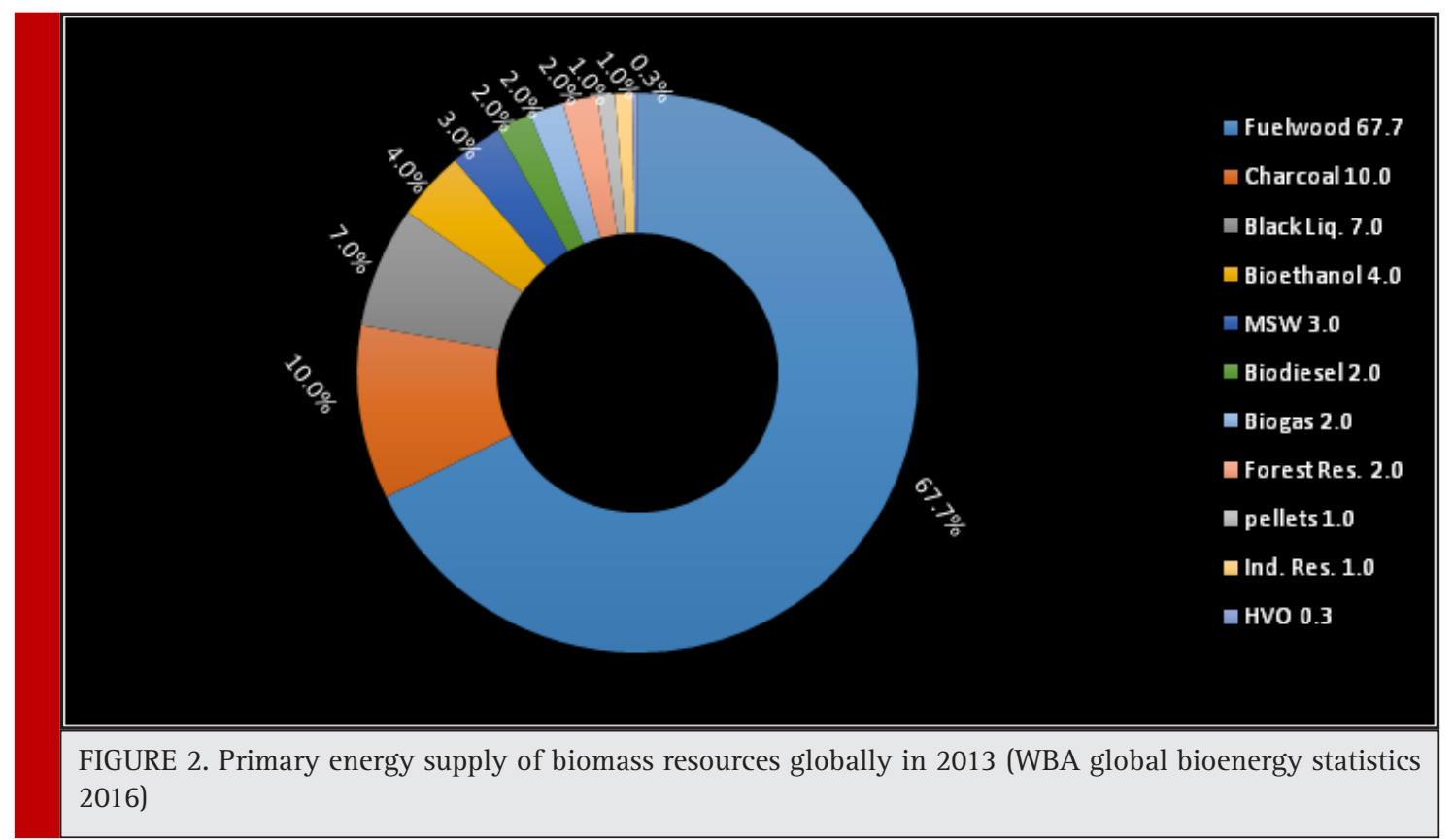

Palm (Arecaceae): Palm oil can be used to create biodiesel. It can be used as a simply processed.

Palm oil mixed with petro diesel, or can be processed through trans esterification to create a palm oil methyl ester blend (Senthil et.al 2015), Byproduct of trans esterification is glycerin. The real process used to produce biodiesel all over the world is different in different countries and as per the requirements of different markets. The next-generation biofuel production processes are being tested in relatively small trial quantities.

Oilseed crops: Biodiesel is produced from oilseed crops like rapeseed, soybean and oil palm but like sugar and

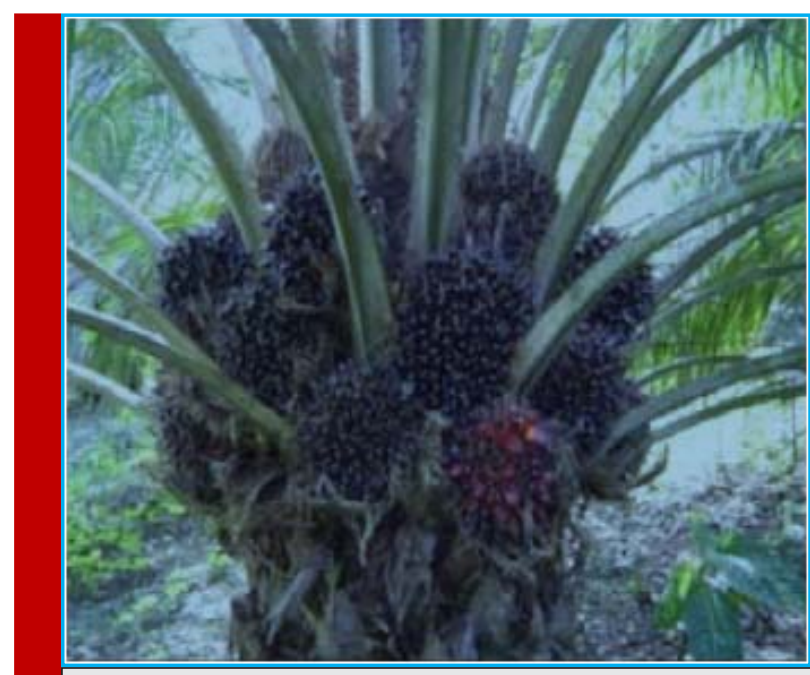

FIGURE 3. Palm tree (Arecaceae) [Source book on REN. Energy ISBN N0: 978-93-81191-09-9] starch crops, oilseed crops are also characterized by low yield and high use of inputs.

Wood: Wood is mainly used for cooking and heating at the household level and for producing electricity at a small scale. When used directly at the household level, it is generally collected from forests or other lands. Commercial plantations of woody trees like poplar in temperate zones and eucalyptus and acacia exist today albeit on a small scale. Today the predominant use of commercial plantations is for the supply of wood to paper and pulp industries. Future cellulosic technologies, which permit the conversion of wood to ethanol (Mohan et al 2006), may compete with general uses of wood.

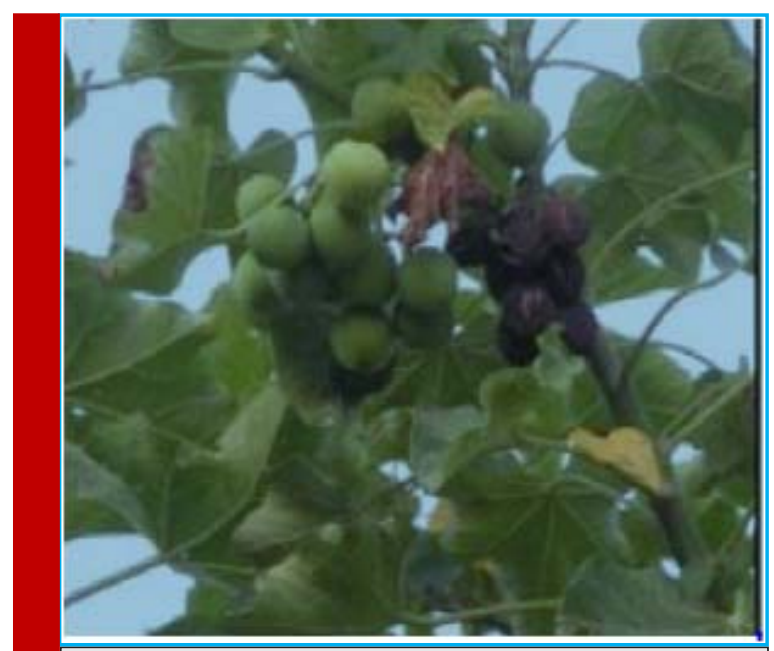

FIGURE 4. Jatropha (Jatropha curcas) (Source book REN. Energy 2017) 
Pongamia pinnata: Pierre is a fast-growing leguminous plant with the potential for high oil seed production and it has the ability to grow on marginal land. All these properties support the suitability of this plant for largescale vegetable oil production required by a biodiesel industry. The future success of $P$. pinnata as a source of feedstock for the biofuels industry is dependent on an extensive knowledge of the genetics, propagation and physiology of this legume. Moreover $P$. pinnata has recently been recognized as a viable source of oil for the burgeoning biofuel industry.

Wastes and residues: The global annual potentional bioethanol from crop residues and waste crops is $491 \mathrm{GL}$ [IEA 2017]. After the processing of one ton of the main product, 1.5 tons of crop residues are generated [Neetu et. al 2015]According to a report there are about 73.9 million tonnes of dry wasted crops and about 1.5 billion tonnes of dry ligno-cellulosic biomass from seven crops namely, oats, barley, maize, rice, sorghum, wheat, and sugarcane. These could yield around 490 billion liters of ethanol or around 30\% of global gasoline use today (Kim et al 2008). 2.12 EJ of waste was converted to energy globally - large part of it was from municipal waste from households and industries also the waste to energy sector has increased at an annual rate of 4\% during 2000 - 2014.55\% of all waste to energy conversion occurs in Europe while the rest is in Asia and Americas, (WBA report 2017).

Jojoba (Simmondsia chinensis): Jojoba oil is the liquid wax produced in the seed of the jojoba (Simmondsia chinensis) plant, a shrub native to southern California, southern Arizona, and northwestern Mexico. The oil makes up about $50 \%$ of the jojoba seed by weight. Unrefined jojoba oil looks like a clear golden liquid at room temperature with a slightly fatty odor. Refined jojoba oil is odorless and colorless. The melting point of jojoba oil is approximately $10^{\circ} \mathrm{C}$ and the iodine value is approximately 80, (Lou et al 2017 ) Jojoba oil is comparatively shelf-stable when compared with other vegetable oils because it does not contain triglycerides, unlike most other vegetable oils such as grape seed oil and coconut oil. It has an Oxidative Stability Index of about 60, which means that it is more shelf-stable than oils of canola oil, safflower oil, almond oil or squalene but less than coconut oil and castor oil.

Jatropha (Jatropha curcas): Jatropha is a genus of flowering plants in the spurge family, Euphorbiaceous, (Divakara et. al 2010). Most of these plants are native to the Americas, with 66 species found in the Old World. Mature plants produce male and female flowers separately. In 2007 Goldman Sachs acknowledged Jatropha curcas as one of the best candidates for future biodiesel production. Healthy seeds (Bold) showed higher oil content $(29.5 \%$ to $36.8 \%)$ as compared to the Shrunken seeds (3.5\% to 8.8\% (Aruna et. al 2017).

On crushing the jatropha seeds, the resulting jatropha oil can be processed to produce a high-quality biodiesel (Kazi et al 2010) that can be used further in a standard diesel car, while the left over residue (press cake) can also be processed and used as biomass feedstock to power electricity plants or used as fertilizer. However, despite their abundance and use as oil, none of the Jatropha species have been properly domesticated, hence their productivity is variable, and the long-term impact of their use on soil quality and the environment is unknown. Estimates of Jatropha seed yield vary widely, due to the lack of research data, genetic diversity of the crop, the range of environments in which it is grown, and Jatropha's perennial life cycle. Seed yields can range from 1,500 to 2,000 kilograms per hectare, corresponding to extractable oil yields of 540 to 680 liters per hectare (Bhupender et al 2012) or 58 to 73 US gallons per acre. Time magazine 2014 acknowledged the potential for as much as 1,600 gallons of diesel fuel per acre per year.

\section{IMPACTS ON ENVIRONMENT AND BIODIVERSITY}

The biodiversity impact of biofuels will depend on the biofuel crop and the previous land use. Biofuels can be beneficial to biodiversity when appropriate crops are grown in suitable areas. Furthermore, if they contribute to climate change mitigation, they have the potential to be indirectly beneficial to biodiversity as a whole. However, biofuels have already been shown to negatively impact biodiversity when direct conversion of natural ecosystems or indirect land conversion of non-degraded land occurs. The expansion of biofuel production in the tropics has resulted in the loss of tropical forest and wetlands, and in temperate regions biofuel production has encroached into set-aside lands. Biofuel feedstock plantations (particularly oil palm and maize plantations), have been shown to support far lower levels if biodiversity than natural ecosystems, and can cause soil erosion and the pollution of watercourses. How a feedstock plantation is managed influences the level of biodiversity impacts. Well managed plantations can in some instances prove beneficial to biodiversity especially if these are on degraded or marginal lands. Biofuel targets have largely been set as part of renewable energy policies in the context of climate change mitigation. Biofuels can undoubtedly contribute to climate change mitigation when grown in appropriate areas. For example, recent studies have suggested that when sugarcane is used to produce ethanol, $80-100 \%$ greenhouse 
gas savings could be achieved (Howarth et al 2009), and that oilseed rape production for biodiesel can similarly achieve emissions savings of 20-85\% (Howarth et al 2009).Where biofuels achieve real emissions reductions, this would have biodiversity benefits through reducing climate change impacts, (UN-Environment report 2017).

This is an important trade-off to keep in mind when considering some of the potential negative impacts on biodiversity resulting from the cultivation of feedstocks. Moreover, the time frame, over which the impacts on biodiversity resulting from biofuel production are examined, also needs to be considered. However, recent research has suggested that the production of energy crops may do little to mitigate climate change where they replace natural ecosystems; even increasing emissions by as much as 17-420 times compared to that of fossil fuels (Fargione et al 2008). One recent study has estimated that land conversion for biofuels could result in emissions of 753-1825 Mt CO2 per year, compared to the 840 Mt CO2 that is emitted from 10\% petrol consumption (Ravindernath et al 2009). Furthermore, although the use of palm oil can achieve large greenhouse gas emissions savings, the conversion of rainforest and peat soils can actually result in $800-2000 \%$ higher emissions than equivalent fossil fuels.

Net carbon reduction: This refers to the net reduction in carbon emissions resulting from the consumption of a unit of biofuel. Biofuels are generally expected to result in lower net addition of carbon to the atmosphere because the carbon emitted on combustion is eventually sequestered during re cultivation, whereas carbon emitted during combustion of fossil fuels is more (Kevin et al 2011).

Net petroleum offset: This refers to the reduction in petroleum consumption that can be achieved by using biofuel. One way to measure the net petroleum offset is to calculate the number of gallons of gasoline displaced by one gallon of ethanol. This indicator can be useful for studying the implications of biofuel for oil depletion, oil imports, etc.

Reducing land conversion: biodiversity impact will largely depend upon the previous land use. Although planting second generation biofuels on degraded land could reduce natural land conversion whilst providing soil stability, nutrients, and increasing water retention. It has been estimated that yields of grassland perennials are 50\% higher if grown on fertile land, (Ji X and Long et al 2016). Plantations on degraded land would therefore have to be properly incentivized, and it has been suggested that regulations would be required to stop crops such as switchgrass being grown like traditional biofuels. Land compatible with switchgrass is the same as that currently set-aside under the USDA Conservation Reserve Programmed, and it is likely that biodiverse 'prairies', pasture land and cropland would be required to meet biofuel targets. Similarly, incentives for short rotation coppice (SRC) could result in the conversion of forest to poplar and willow plantations.

Conversion of degraded or marginal lands: When appropriate crops are planted in suitable areas, they can actually benefit biodiversity. This is particularly true where biofuels are grown on marginal and degraded lands. They can increase soil productivity, reduce soil erosion, reduce pressure on natural ecosystems, and create habitats. Jatropha is one biofuel crop that can be grown on degraded land and is receiving increasing attention, particularly in Africa and India. It has been suggested that this crop can be grown by traditional pastoralists under traditional systems that maintain biodiversity and it is not a crop used for food production. However, its land and water requirements and suitability for large scale production are yet to be fully determined, and reports suggest that it will grow better on more productive land meaning that production on degraded land would need to be incentivized. On the other hand, some countries currently have biofuel crops on no sensitive lands or still have large expanses of such land available for energy crop production (UNCTAD 2016).

Temperate ecosystems: The European Environment Agency is concerned that the profitability of biofuels will outweigh the incentives for farmers to participate in agro-environmental schemes (House of Commons Environmental Audit Committee 2016). This is a significant issue for biodiversity, particularly for bird species, as it has been estimated that set-aside lands in the US have bird nesting rates that are ten times higher than those on cropland. In Europe, encroachment into set-aside land by oilseed rape and sugar beet threatens semi-natural steppes and long fallow dry cereal systems, which are among Europe's most biodiverse habitats. This has been linked to a decline in key habitats for endangered species (WWF Report 2016) and to declines in farmland birds (Brown et al 2008). A recent study of the potential biodiversity impacts of biofuel policy in Europe has suggested that although impacts will vary spatially and depend upon crop choice, they will be negative across all taxa and particularly so for mammals.

Post land conversion impacts: the true environmental impacts of biofuels are often overlooked. Life cycle analyses (LCAs) provide a mechanism for these impacts to be assessed. Along with greenhouse gas emission, LCA provides a mechanism for investigating biofuels' potential for acidification, eutrophication, toxicity, photochemi- 
cal ozone, and ozone and resource depletion. However, few LCAs provide a comprehensive coverage of potential environmental impacts and impacts on biodiversity are not covered due to a lack of indicators Although overlooked, the pollution from fertilizers and pesticides is likely to be another major negative biodiversity impact associated with biofuels; particularly for aquatic ecosystems (Sala et al. 2009).

One study on the environmental impact of sugarcane plantations has shown that soil erosion is high in plantations in comparison to forest and pasture, and that the resulting sediments are deposited into wetlands, rivers, and streams. The same study noted that watersheds in major sugarcane areas had only $13-18 \%$ of the original riparian vegetation, which has led to decreasing small mammal species richness (Johnston et al. 2009). However, the cultivation of appropriate native species could result in less pollution, water stress and provide wildlife habitats .The environmental impacts of corn-based ethanol (a fertilizer and pesticide intensive crop) are thought to be the highest of any agricultural crops in the US. Again, many of these impacts are felt downstream, making it difficult to quantify. For example, ethanol production in the Mississippi River system has been linked to hypoxia in the Gulf of Mexico. In addition, biofuel crops can cause water stress. Many of the crops require heavy irrigation, which can involve the drainage of wetlands and use of water from rivers and lakes, with consequent implications for biodiversity (AEA Technology 2008).

Despite this, in-depth studies into the water footprints of different biofuel crops are only just becoming available. There is also significant concern that some biofuel crops will be invasive in some areas. For example, a study in Hawaii has suggested that $70 \%$ of regionally suitable biofuel crops have a high risk of becoming invasive, compared to only one quarter of the non-biofuel plant species assessed (Carolina et.al 2011). Biofuels that do not require high-energy inputs and can be grown in polycultures of native species will be more biodiversity friendly than monocultures. This does not apply to most of the first generation biofuels, but it has been suggested that the development of second-generation biofuels such as grassland perennials could potentially lead to more 'biodiversity friendly' biofuel production monocultures. Choice of crop and management regime is therefore an important element in determining whether impacts on biodiversity are positive or negative. The 'off farm' impacts of biofuel production will be similar to those observed from conventional agriculture, a full analysis of which is beyond the scope of this report. These impacts have been reviewed and related to biofuels in a report by AEA Technology for the UK government (AEA Technology 2008).

\section{PRODUCTION}

With the recent famous climate agreement COP21 in Paris, will be the driver of the investments in bioenergy. The agreement will provide highly needed impetus in shifting from fossil fuels to renewables. Greenhouse gas (GHG) mitigation is also a major driver for development of bioenergy markets, in recent years. Earlier it was often noticed that the security of supply and high import costs of fossil fuels was the main argument. Now, the substitution of fossil fuels, and the reduction of fos-

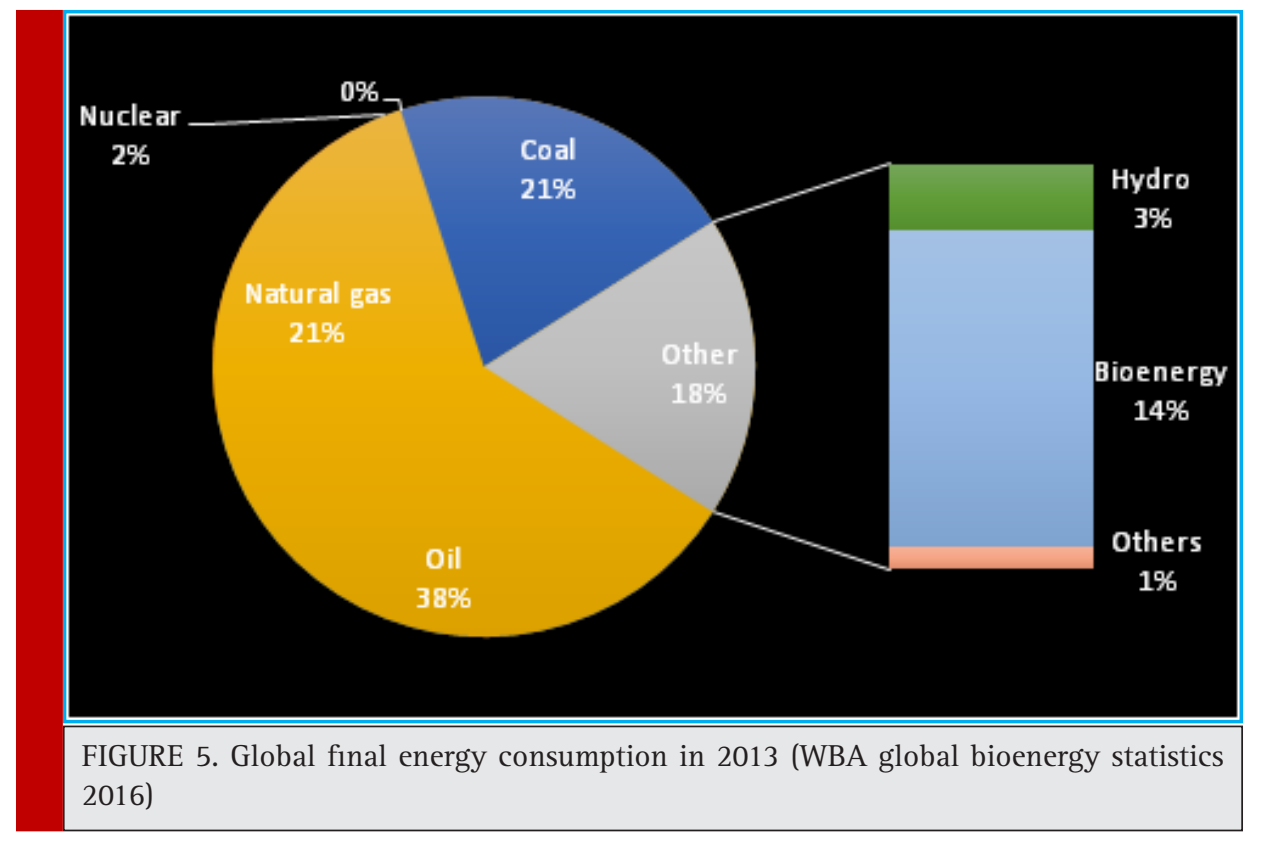




\begin{tabular}{|c|c|c|c|}
\hline Sr. No & Country & Ethanol blend percentage & Biodiesel blend percentage \\
\hline 1 & Brazil & $27.5 \%$ & $7 \%$ \\
\hline 2 & Paraguay & $25 \%$ & $1 \%$ \\
\hline 3 & India & $5 \%$ & - \\
\hline 4 & Jamaica & $10 \%$ & - \\
\hline 5 & Philippines & $10 \%$ & $10 \%$ \\
\hline 6 & Argentina & $10 \%$ & $5 \%$ \\
\hline 7 & Costa Rica & $7 \%$ & $20 \%$ \\
\hline 8 & EU & $10 \%$ (food crop biofuels limited to $7 \%$ ) & - \\
\hline 9 & Canada & National: 5\% & National: $2 \%$ \\
\hline 10 & China & 10\% (in nine provinces) & - \\
\hline
\end{tabular}

sil carbon emissions are major arguments and benefits for bioenergy. Another major driver is the carbon taxes, a key instrument for energy transition. Carbon tax is a simple and effective tool to reduce fossil fuel use and increase energy efficiency. It can be tax neutral as other taxes like income tax can be reduced. This will also lead to a more sustainable lifestyle and investment for the future. To put the Paris agreement into concrete action, there has been a global call for introduction of carbon pricing. It was one aspect in which everyone was in agreement including companies, NGOs, governments etc. Efforts are underway for initiating a global carbon price. Many countries, for example Sweden, have successfully implemented the carbon tax leading to an increase use of bioenergy.

In Europe and North America the use of biomass for electricity is prominent. Highly produced from forestry products and residues. Cogeneration plants enable the use of biomass with increased efficiency, so much so that the combined efficiency of producing heat and electricity more 80\%. The Europe and Americas continent contribute more than $70 \%$ of all consumption of biomass for electricity. In 2013, 462 TWh of electricity was produced globally from biomass (WBA Report 2016). In the past few years, biomass is work more effective in developing countries in Asia and Africa where popula-

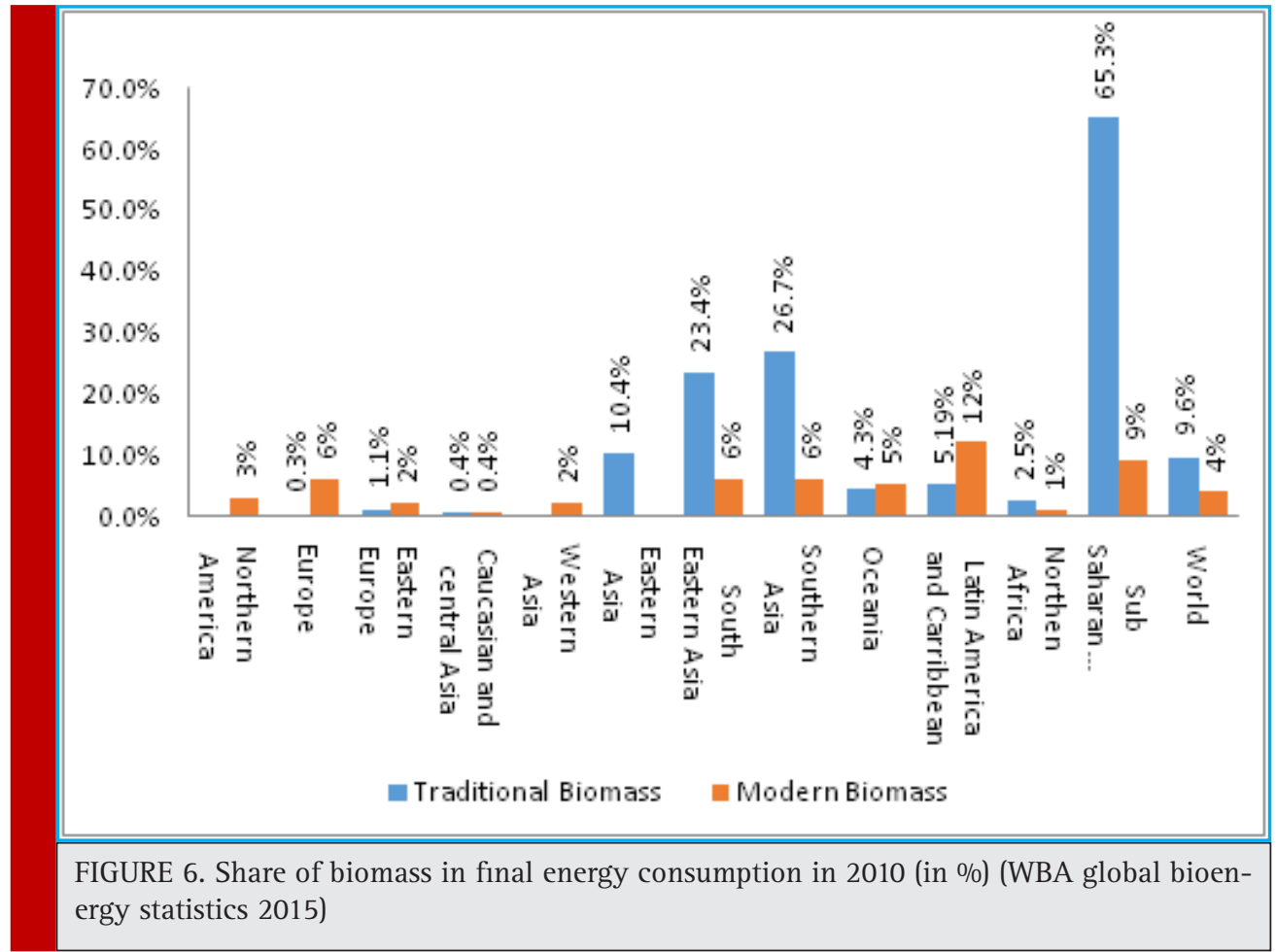




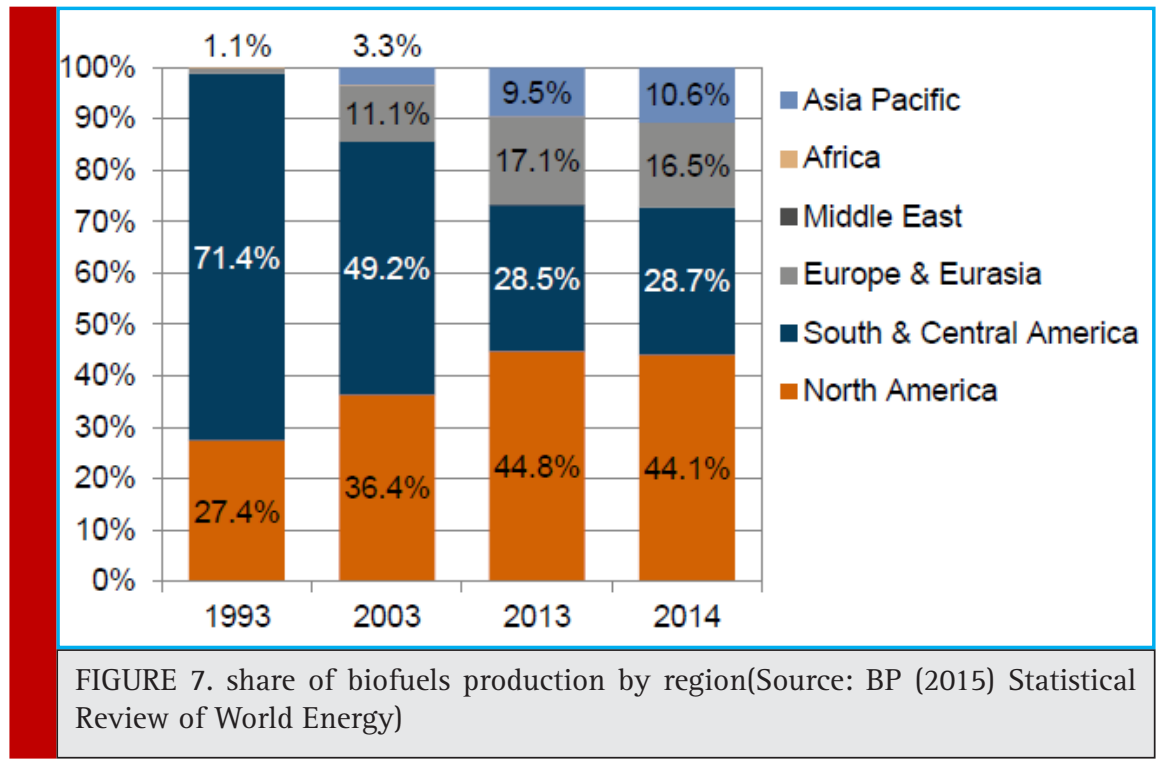

Table 2. Biomass production and gross electricity generation from biomass by different countries (source WEC 2016)

\begin{tabular}{|l|l|l|l|}
\hline Year & Country & $\begin{array}{l}\text { Biomass } \\
\text { production } \\
\text { in tonne } \\
\text { of oil } \\
\text { equivalent }\end{array}$ & $\begin{array}{l}\text { Gross } \\
\text { electricity } \\
\text { generation } \\
\text { from biomass } \\
\text { in tonne of oil } \\
\text { equivalent }\end{array}$ \\
\hline 2013 & Argentina & 2261919 & 212038 \\
\hline 2013 & Austria & 4376995 & 295529 \\
\hline 2013 & Belarus & 1505136 & 7395 \\
\hline 2014 & Belgium & 1104090 & 226226 \\
\hline 2013 & Benin Republic & 2230917 & 86 \\
\hline 2013 & Bolivia & 999403 & 4816 \\
\hline 2013 & Brazil & 67195353 & 3438264 \\
\hline 2014 & Bulgaria & 1086510 & 11866 \\
\hline 2013 & Cambodia & 3999929 & 946 \\
\hline 2013 & Cameroon & 4778184 & 5847 \\
\hline 2013 & Canada & 11468425 & 373517 \\
\hline 2013 & Chile & 10235383 & 491918 \\
\hline 2013 & China & 200962120 & 3293208 \\
\hline 2013 & Colombia & 3929947 & 170164 \\
\hline 2013 & Costa Rica & 674501 & 15736 \\
\hline 2013 & Cote d'Ivoire & 9640896 & 5847 \\
\hline 2013 & Cuba & 1235049 & 58470 \\
\hline 2014 & Czech Republic & 2300994 & 171282 \\
\hline 2014 & Denmark & 1304505 & 254343 \\
\hline 2013 & Ecuador & 554481 & 25452 \\
\hline 2013 & El Salvador & 779450 & 34136 \\
\hline 2013 & Estonia & 1122099 & 62855 \\
\hline & & & \\
\hline
\end{tabular}

\begin{tabular}{|c|c|c|c|}
\hline 2014 & Finland & 8066400 & 943079 \\
\hline 2014 & France & 9073899 & 140843 \\
\hline 2013 & Gabon & 1262850 & 860 \\
\hline 2014 & Germany & 11424692 & 1020465 \\
\hline 2013 & Greece & 869208 & 18573 \\
\hline 2013 & Guatemala & 7561432 & 154515 \\
\hline 2013 & Honduras & 2258073 & 62425 \\
\hline 2013 & Hungary & 1402790 & 146346 \\
\hline 2013 & India & 398969 & 179544 \\
\hline 2013 & Indonesia & 54240686 & 19605 \\
\hline 2013 & Iran & 498448 & 1978 \\
\hline 2013 & Ireland & 210400 & 22528 \\
\hline 2013 & Israel & 20350 & 7223 \\
\hline 2014 & Italy & 6539410 & 328719 \\
\hline 2013 & Jamaica & 493838 & 16681 \\
\hline 2013 & Japan & 8461069 & 2760706 \\
\hline 2013 & Kenya & 15392 & 15392 \\
\hline 2014 & Luxembourg & 65803 & 1806 \\
\hline 2013 & Malaysia & 3505040 & 95271 \\
\hline 2013 & Mauritius & 209015 & 40671 \\
\hline 2013 & Mexico & 8867632 & 87619 \\
\hline 2014 & Netherlands & 1290103 & 180568 \\
\hline 2013 & New Zealand & 1081471 & 33964 \\
\hline 2014 & Norway & 840499 & 1032 \\
\hline 2013 & Philippines & 7793375 & 13070 \\
\hline 2013 & Poland & 6179493 & 787705 \\
\hline 2013 & $\begin{array}{l}\text { Republic of } \\
\text { Korea }\end{array}$ & 952542 & 42993 \\
\hline 2014 & Romania & 3645696 & 39037 \\
\hline 2013 & Slovakia & 759507 & 78762 \\
\hline
\end{tabular}




\begin{tabular}{|l|l|l|l|}
\hline 2013 & South Africa & 15554123 & 25624 \\
\hline 2014 & Sweden & 8958107 & 780482 \\
\hline 2013 & Switzerland & 1002437 & 26140 \\
\hline 2013 & Tanzania & 20049036 & 1806 \\
\hline 2013 & Thailand & 22577936 & 528031 \\
\hline 2013 & Turkey & 3152193 & 3010 \\
\hline 2013 & Ukraine & 1880769 & 8685 \\
\hline 2014 & $\begin{array}{l}\text { United } \\
\text { Kingdom }\end{array}$ & 3047794 & 1281858 \\
\hline 2013 & $\begin{array}{l}\text { United States } \\
\text { of America }\end{array}$ & 51375036 & 3915306 \\
\hline
\end{tabular}

tion is dense and access to electricity is low. There is a cost competition in Biogas and decentralized bioenergy systems. It is found that cogeneration plants using agricultural residues like Bagasse in India, Mauritius, Kenya and Ethiopia are successful.

According to REN21 2015 global status report USA National: The Renewable Fuels Standard 2 (RFS2) requires 136 billion liters of renewable fuel to be blended yearly with transport fuel by 2022. Also Table 1 show Ten countries where ethanol and biodiesel mandatory mix

\section{CONCLUSION}

Bioenergy reduced dependency of countries on fossil fuels and enhance in a gradual decarburization of the energy system. In present date countries like Finland and Sweden have successful utilization of bioenergy. Their sustainable use forest products or forestry make them to be world leaders in renewables. Data show Brazil has maximum blending of biofuels in the transportation sector and becoming independent of oil. This is possible only because of effective policies such as carbon taxes, blending mandates and high investments in research and development. These policies have been driven by strong support from the technical institution, associations and companies. Also Countries in Asia and sub-Saharan Africa has led to an increasing dependence on biomass. It has provided much energy to rural areas which is highly needed and is the source of livelihood in many countries

\section{ACKNOWLEDGEMENT}

While bringing out this research paper to its final form, we came across a number of people whose contributions in various ways helped in this field of research and they deserve special thanks. It is a pleasure to convey our gratitude to all of them

\section{REFERENCES}

\section{AEA Technology Report 2008}

Anil Kumar,Nitin Kumar, Prashant Baredar, Ashish Shukla (2015) .A review on biomass energy resources, potential, conversion and policy in India Renewable and Sustainable Energy Reviews : Elsevier

Aonymous REN (2017)A book on Renewable Energy Sources and Their Application ISBN NO: 978-93-81191-09-9

Aruna R Prakash, Ch. Ravi Prakash, Sarnam Singh, Arup Ghosh and Pradeep K Agarwal (2017). Selection of reproductive traits and oil content assessment for better parental combination in Jatropha curcas L. breeding program MAYFEB Journal of Agricultural Science Vol 1 (2017) - Pages 39-48

Bhupender Singh and Jaikishan H.M. (2012) Trees and plant biomass: As a Source of Bioenergy and Bioelectricity

BP Statistical Review global of World Energy-2015

Brown,L. (2008) Biofuels: renewable energy or environmental disaster in the making? Worldwatch Institute

Carolina Cardoso Lisboa, Klaus Butterbach-Bahl, Matthias Mauder, Ralf Kiese (2011) Bioethanol production from sugarcane and emissions of greenhouse gases - known and unknowns GCB Bioenergy Vol.3 issue 4 pages 277-292

Divakara, B.N., Upadhyaya, H.D., Wani, C.L. and Gowda, L. 2010. Biology and genetic improvement of fuel producing plants

Fargione,J., Hill,J., Tilman,D., Polasky,S. \& Hawthorne,P. (2008) Land clearing and the biofuel carbon debt. Science, 319, $1235-1238$

Honary L. (2008)A textbook on Biobased Lubricants and Greases By Lou Honary, Erwin Richter House of Commons Environmental Audit Committee Report 2017

Howarth, R.W., Bringezu, S., Bekunda, M., de Fraiture, C., Maene, L., Martinelli, C., Maene, L. \&t Sala, 0. (2009) Rapid assessment on biofuels and environment: overview and key findings. Pages 1-13

IEA Report 2017 on Jatropha curcas L.: A review. Applied Energy, 87(3): 732-742

Ji, X.; Long, X. (2016). A Review of the Ecological and Socioeconomic Effects of Biofuel and Energy Policy Recommendations. Renew. Sustain. Energy Rev. 61, 41-52

Johnston, M., Foley, J.A., Holloway, T., Kucharik, C. \& Monfreda, C. (2009) Resetting global expectations from agricultural biofuels. Environmental Research Letters, 4, 014004

Kevin Bulls (2011) Do Biofuels Reduce Greenhouse Gases? A new study fuels the debate over the impact of growing crops for fuel MIT Technology Review

Mohan D, Pittman Jr CU, Steele PH. ( 2006) Pyrolysis of wood/ biomass for bio-oil: a critical review. Energy Fuels;20:84889

Moonmoon Hiloidhari, Dhiman Das, D.C.Baruah (2014) Bioenergy potential from crop residue biomass in India. Renewable and Sustainable Energy Reviews : Elsevier 
Neetu Mahawar, Priya Goyal Sunita Lakhiwal and Sakshi Jain (2015) Agro Waste: A New Eco- Friendly Energy Resource International Research Journal of Environment Sciences ISSN 2319-1414 Vol. 4(3), 47-49,

Plant Research International 2012. JATROPT (Jatropha curcas): Applied and technical research

Prasad S, Singh A, Joshi HC. (2007) Ethanol as an alternative fuel from agricultural, industrial and urban residues. http:// www.pri.wur.nl/UK/research .(accessed January 05, 2018

Ravindranath,N.H., Manuvie,R., Fargione,J., Canadell,J.G., Berndes,G., Woods,J., Watson,H. \&t Sathaye,J. (2009) Greenhouse gas implications of land use and land conversion to biofuel crops. Pages 111-125 In R.W. Howarth and S. Bringezu (eds) Gummersbach Germany. Cornell University, Ithaca NY, USA

REN21 Global Status Report 2017

REN21 Global Status Report 2015

S.Senthilkumar ,G.Sivakumar, Siddarth Manoharan (2015) Investigation of palm methyl-ester bio-diesel with additive on performance and emission characteristics of a diesel engine under 8-mode testing cycle (2015) Alexandria Engineering Journal Volume 54, Issue 3, Pages 423-428

Sadhan Kumar Ghosh (2014) Biomass \& Bio-waste Supply Chain Sustainability for Bio-energy and Bio-fuel Production
The Tenth International Conference on Waste Management and Technology (ICWMT): Elsevier

Sala,O.E., Sax,D. \&t Leslie,H. (2009) Biodiversity consequences of biofuel production. Pages 127-137 In R.W. Howarth and S. Bringezu (eds) Biofuels: Environmental Consequences and Interactions with Changing Land Use. Proceedings of the Scientific Committee on Problems of the Environment (SCOPE) International Biofuels Project Rapid Assessment, 22-25 September 2008, Gummersbach Germany. Cornell University, Ithaca NY, USA

Seungdo Kim Bruece dale (2004) Global Potential bioethanol Production from Wasted Crops and Crop Residues. Biomass and Bioenergy vol.26 issue 4 pages $361-375$

Time magazine 2014

UNCTAD Report 2016

UN-Environment report 2017

WBA bioenergy statistics 2015

WBA bioenergy statistics 2017

WBA global bioenergy statistics 2016

World Energy Council Report 2016

World energy resources Bioenergy report (2016) by World Energy Council

WWF Annual Report 2016 